\title{
Novel variants in established hypopituitarism genes expands our knowledge of phenotypic spectrum
}

Marilena Nakaguma ${ }^{1}$, Nathalia Ferreira ${ }^{1}$, Anna Flavia Benedetti ${ }^{1,2}$, Mariana Madi ${ }^{1}$, Juliana M Silva ${ }^{1}$, Sally A Camper ${ }^{3}$, Jun $\mathrm{Li}^{3}$, Qianyi $\mathrm{Ma}^{3}$, Asye B Ozel ${ }^{3}$, Qing Fang ${ }^{3}$, Amanda de Moraes Narcizo², Laís Cavalca Cardoso², Luciana Ribeiro Montenegro ${ }^{1,2}$, Mariana Ferreira de Assis Funari ${ }^{1,2}$, Mirian Yumie Nishi ${ }^{1,2}$,Berenice B Mendonca ${ }^{1,2}$, Ivo J P Arnhold ${ }^{1}$, Alex A L Jorge ${ }^{4}$, Luciani R Carvalho ${ }^{1}$.

${ }^{1}$ Developmental Endocrinology Unit, Laboratory of Hormones and Molecular Genetics LIM/42, Division of Endocrinology, Hospital das Clinicas da Faculdade de Medicina da Universidade de São Paulo (FMUSP), São Paulo, Brazil

${ }^{2}$ Laboratorio de Sequenciamento em Larga Escala (SELA), Faculdade de Medicina FMUSP, Universidade de Sao Paulo, Sao Paulo, SP, BR.

${ }^{3}$ Department of Human Genetics, University of Michigan, Ann Arbor, MI, USA

${ }^{4}$ Genetic Endocrinology Unit (LIM25), Division of Endocrinology, Hospital das Clinicas da Faculdade de Medicina da Universidade de São Paulo (FMUSP), São Paulo, Brazil

\section{Abstract}

We report four allelic variants (3 novel) in three genes previously established as causal for hypopituitarism or related disorders. A novel homozygous variant in the growth hormone gene, GH1 c.171delT (p. Phe 57Leufs * 43), was found in a male patient with severe isolated growth hormone deficiency (IGHD) born to consanguineous parents. A SOX3 allelic variant (p.Met304lle) was found in a male patient with IGHD and hypoplastic anterior pituitary. YASARA, a tool to evaluate protein stability, suggests that p.Met304lle destabilizes the SOX3 protein $(\Delta \Delta G=2.49 \mathrm{kcal} / \mathrm{mol})$. A rare, heterozygous missense variant in the TALE homeobox protein gene, TGIF1 (c.268C>T:p.Arg90Cys) was found in a patient with combined pituitary hormone deficiency (CPHD), diabetes insipidus, and syndromic features of holoprosencephaly (HPE). A novel heterozygous TGIF1 variant (c.82T>C:p.Ser28Pro) was identified in a patient with CPHD, pituitary aplasia and ectopic posterior lobe. Both TGIF1 variants have an autosomal dominant pattern of inheritance with incomplete penetrance. In conclusion, we have found allelic variants in 3 genes in hypopituitarism patients. We discuss these variants and associated patient phenotypes in relation to previously reported variants in these genes, expanding our knowledge of the phenotypic spectrum in patient populations.

\section{Introduction}

Congenital hypopituitarism is a rare disorder with a prevalence of $1 / 3000$ to $1 / 4000$ births, characterized by deficient production of one or more pituitary hormones ${ }^{1}$. Clinical manifestations are variable. Pituitary hormone deficiency can occur with or without syndromic features, manifest early at birth or during infancy, and progress with age 2;3;4.

Genetic investigation is fundamental to understand pituitary development and to allow early diagnosis and genetic counseling. Early studies used Sanger sequencing of candidate genes such as transcription factors expressed during the pituitary embryogenesis in mice ${ }^{3}$. 
In the last 2 decades, pathogenic allelic variants in more than 30 genes were recognized as a cause of congenital hypopituitarism ${ }^{3}$. The application of massively parallel sequencing, in targeted gene panels, exomes or whole genomes, has made it possible to identify new genes and rare variants involved in pituitary development and disease and to expand the phenotype associated with previously known genes $5 ; 6 ; 7 ; 8$; 9; 10;11;12;13;14. Genotype-phenotype correlations are still difficult to discern, given the variability of features among patients with lesions in the same gene.

In this paper we describe variants in GH1, SOX3 and TGIF1, three genes that are already associated with hypopituitarism. These variants were identified by exome sequencing or by sequencing a panel of selected genes in a large cohort of patients with combined pituitary hormone deficiency ascertained in a single Brazilian center.

\section{Materials and Methods}

\section{Ethical Procedures}

All patients gave their permission to take part of the present study that was approved by the Brazilian national ethical committee under the number CAAE 0642812.4.0000.0068

\section{Patients}

The patients described here in detail are followed in the endocrinology clinic at the Hospital das Clinicas, University of São Paulo Medical School.

\section{DNA extraction}

DNA was extracted from the peripheral blood sample using salting out method 15.

\section{Filtering process and sequencing analysis}

Exome and panel variant sequencing analysis were similar, as they were performed in isolated patients. The filtering pipeline took into consideration exonic and splice site regions, as well as Minor Allele Frequency (MAF) of less than $1 \%$ in international and national populational databases: gnomAD (gnomad.broadinstitute.org), 1000 Genomes, ABraOM (abraom.ib.usp.br) ${ }^{16}$ and internal database SELAdb (intranet.fm.usp.br/sela) ${ }^{17}$. First, homozygous variants were considered assuming an autosomal recessive disorder. If no variants of interest were evident, the search was expanded to heterozygous variants. Prediction algorithms such as MutationTaster, MutationAssessor, SIFT, PolyPhen2, and Human Splicing Finder were used to determine which variants were deleterious. Variants were then classified according to recommendations of the American College of Medical Genetics (ACMG/AMP) with the help of Varsome (varsome.org).

\section{Bioinformatics tools to check allelic variant impact}

We used the RNAfold server from ViennaRNA Web Services to predict mRNA secondary structure (http://rna.tbi.univie.ac.at/cgi-bin/RNAWebSuite/RNAfold.cgi). We determined RNA base pair probability and optimal folding for SOX3 wild type mRNA (Met304), a polymorphism (Met304Val), and the candidate variant (Met304lle).

Protein stability was calculated using YASARA (http://yasara.org) via the FoldX plugin (http://foldxsuite.crg.eu/). A variant was considered destabilizing when $\Delta \Delta G$ was positive, taking into consideration the tool's error margin of $\Delta \Delta \mathrm{G}= \pm 0.5 \mathrm{kcal} / \mathrm{mol}$. 


\section{Results}

\section{Patient 1 with allelic variant GH1 c.171delT, p.Phe 57Leufs ${ }^{\star} 43$, Chromosome position 17:61995706:A:-}

Clinical, laboratory, and image features

A male patient, age 9.5 years, presented at his first visit with a height of $87 \mathrm{~cm}$ (-7.65 SD) and delayed bone age by 4.6 years (Table 1). A clonidine stimulation test confirmed growth hormone (GH) deficiency with a GH peak $<0.25 \mathrm{ng} / \mathrm{dl}$ which, for the radioimmunoassay method, was considered unresponsive with $\mathrm{GH}<7 \mathrm{ng} / \mathrm{dl}$. In the first year of treatment with somatotropin, a good response was obtained with a growth rate of $16.9 \mathrm{~cm} /$ year and a delta Z-score of 2.18 (height at the end of first year -5.47 SD) (Table 1). Magnetic resonance imaging (MRI) revealed a normal pituitary with visualizable stalk and appropriately positioned neurohypophysis (Table 2).

Puberty occurred spontaneously at age 14 years, and a pubertal block was administered from 14 years and 8 months to 16 years and 7 months. His final height was $170.5 \mathrm{~cm}$ (-0.63 SD) (Table 1). The patient had bilateral cryptorchidism, which was surgically corrected at age 12 . At the age of 14 , he developed hypergonadotrophic hypogonadism. As an adult he underwent unsuccessful assisted reproduction.

\section{Molecular results}

The parents were first cousins and were unaffected. He had two older sisters and a younger sister. The patient was homozygous for the allelic variant $\mathrm{GH} 1$ c.171delT (p. Phe 57Leufs ${ }^{4} 43$ ), and both the sister (II.4) and mother (I.1) were heterozygous for the variant. The second sister (II.2) died at 5 years of age and had a phenotype suggestive of growth hormone deficiency (GHD), including a saddle nose, frontal bossing, and short stature, but no DNA was available (Figure 1). The other sisters had no abnormal features.

The GH1 variant c.171delT (p.Phe57Leufs*43) has never been described in association with hypopituitarism, either in OMIM or in Genecards. This variant is absent In population databases, including Exome Aggregation Consortium (EXAC), gnomAD, and the Brazilian population databases (SELA and ABraOM) (Table 3). The variant GH1 c.171delT (p.Phe57Leufs ${ }^{*} 43$ ) was visually confirmed using integrated genome viewer (IGV), and it is classified as pathogenic by Varsome ${ }^{18}$.

\section{Patient 2 with allelic variant in SOX3 (c.912G>A;p.Met304lle;X:139586314:C:T)}

Clinical, laboratory and image features.

A male patient, the son of non-consanguineous parents, was born at term, with appropriate weight: $3300 \mathrm{~g}(-0.73$ SDS). There were no perinatal complications, and his neurological development was normal. Short stature was noticed at 2 years of age, and at 6 years of age he was diagnosed with growth hormone deficiency. Somatotropin treatment began at age 7 with an initial height of $95 \mathrm{~cm}(-4.67$ SDS) and was continued to age 15.

Spontaneous puberty occurred at age 13 and was blocked from age 13 and 9 months to age 14 and 8 months. At 16 years and 6 months, his bone age was 16 years, and his final height was $153 \mathrm{~cm}$ (-2.9 SDS) (Table 1). IGF1 was $200 \mathrm{ng} / \mathrm{ml}$ (NV- 
227-964 $\mathrm{ng} / \mathrm{ml}$ ) and in the insulin tolerance stimulation test (ITT), glycemia trough was $32 \mathrm{mg} / \mathrm{dL}$ and maximum peak of $\mathrm{GH} 0.9 \mathrm{ng} / \mathrm{ml}$. Only growth hormone deficiency was confirmed and Somatotropin 1U/day was reintroduced. Magnetic resonance imaging (MRI) presented with pituitary hypoplasia and ectopic neurohypophysis located at the level of the optic chiasm (Table 2).

\section{Molecular results}

Using target gene panel sequencing, a hemizygous variant in the SOX3 gene was found in the male patient: c.912G>A;p.Met304lle;X:139586314:C:T. This variant was not found in any of the population databases, and it is predicted to be deleterious by SIFT, MutationTaster, MutationAssessor and PolyPhen2 (Table 3). The patient's mother, father, brother, sister and maternal uncle were all phenotypically normal and were screened for the variant. Both the mother and sister were carriers. The father, brother and uncle were negative for the variant. (Figure 2a)

The p.Met304lle variant is located just outside the SOXp region (Figure $2 \mathrm{~b}$ and 2c). Two in silico studies were done to better access variant pathogenicity. The c.912G $>$ A substitution is predicted to cause loss of a hairpin in the mRNA secondary structure, although the significance of such a change is unclear (Figure 3). The p.Met304lle variant is predicted to be destabilizing $(\Delta \Delta \mathrm{G}=2.49 \mathrm{kcal} / \mathrm{mol})$ for the protein based on in silico analysis with the YASARA tool. For comparison, the previously reported missense variants p.Ser150Tyr and p.Pro142T were also destabilizing $(\Delta \Delta \mathrm{G}=5.75 \mathrm{kcal} / \mathrm{mol}$ and $5.85 \mathrm{kcal} / \mathrm{mol}$, respectively). Reported polymorphisms were not predicted to change protein stability as the values (p.Arg5Q $\Delta \Delta \mathrm{G}=0.83 \mathrm{kcal} / \mathrm{mol}$ and and p.Met304Val $0.47 \mathrm{kcal} / \mathrm{mol}$ ) are within the tool's error margin of $\Delta \Delta \mathrm{G}= \pm 0.5 \mathrm{kcal} / \mathrm{mol}$.

\section{Patient 3 with allelic allelic variant TGIF1 (c.268C>T;p.Arg90Cys; Chromosome position 18:3457387:C:T)}

Clinical, laboratorial and image features.

A female patient was born to non-consanguineous parents and delivered by caesarean section at 37 weeks. Her twin sister was diagnosed with holoprosencephaly (HPE) and died at birth.

The patient was born small for gestational age: $2505 \mathrm{~g}(-0.75 \mathrm{SDS}), 46 \mathrm{~cm}$ (0.63 SDS) and head circumference $32 \mathrm{~cm}(-0.65)$. The patient presented with severe complications at birth, including prolonged jaundice, hypothermia, hyponatremia and seizures in the first days of life (Table 1). She also had syndromic features that included craniofacial malformation, hypertelorism, and nystagmus. She underwent surgical correction of her cleft palate in her $5^{\text {th }}$ day of life. She was severely affected with significant neuropsychomotor developmental delay and required enteral feeding. At her second month of life, she was diagnosed with congenital hypopituitarism and started replacement with prednisolone $0.6 \mathrm{mg}$ per day, levothyroxine $12.5 \mathrm{mcg}$ per day and desmopressin $0.012 \mathrm{mg}$ per day. Recombinant growth hormone replacement was started when she was 2 years old, and spontaneous menarche occurred when she was 12 years old. Magnetic resonance imaging (MRI) revealed absence of septum pellucidum, semilobar holoprosencephaly with partial fusion of thalamus and basal ganglia, dysgenesis of the corpus callosum, small third ventricle, fusion of frontal lobe, wide communication of lateral ventricle, rudimentary horns and ectopic posterior pituitary (Table 2). 


\section{Molecular results}

Using whole exome sequencing, we identified an allelic variant in TGIF1 (c.268C>T;p.Arg90Cys; Chromosome position 18:3457387:C:T) (Figure 4A) classified by the American College of Medical Genetics (ACMG) and Association for Molecular Pathology (AMP) as likely pathogenic. This variant is absent in ExAC and gnomAD, as well as in the Brazilian population (SELA and ABRAOM) (Table 3). The presence of this variant was confirmed in the patient and in her unaffected father and sister (Figure 4C). The arginine at position 90 is well conserved among species (Figure 4E).

\section{Patient 4 with allelic variant TGIF1 (c.82T>C;p.Ser28Pro; Chromosome position 18:3456417:T:C)}

\section{Clinical, laboratorial and image features.}

A male patient was born to non-consanguineous parents, at term, and weighed $3850 \mathrm{~g} \mathrm{(+1.79}$ SDS) and was $48 \mathrm{~cm}$ long (-0.55 SDS). His neuropsychomotor development was normal. He presented at the age of $4.9 \mathrm{yrs}$ with a height of $86.7 \mathrm{~cm}$ (-4.5 SDS) and a bone age of $2.5 \mathrm{yr}$. A clonidine stimulation test was performed, and the maximum $\mathrm{GH}$ response was $0.4 \mathrm{ng} / \mathrm{ml}$. He was given an insulin tolerance stimulation test (ITT) at $8.6 \mathrm{yr}$, and the $\mathrm{GH}$ peak was $0.1 \mathrm{ng} / \mathrm{mL}$ and cortisol was 7.2 $\mu \mathrm{g} / \mathrm{dL}$ (basal of $8.0 \mu \mathrm{g} / \mathrm{dL}$ ). This confirmed the presence of $\mathrm{GH}$ and ACTH deficiencies (Table 1). He received $\mathrm{rGH}$ replacement from 5 to $19 \mathrm{yrs}$. His growth velocity was 12 $\mathrm{cm} / \mathrm{yr}$ in the first year of treatment, and his final height was $168.5 \mathrm{~cm}$ (SDS - 0.62). He presented a baseline cortisol of $6.0 \mu \mathrm{g} / \mathrm{dL}$ at 9.1 years and started treatment with hydrocortisone acetate. Puberty was induced with testosterone cypionate when he was $14.4 \mathrm{yr}$ (Table 1). MRI revealed pituitary aplasia, interrupted pituitary stalk, and ectopic posterior lobe (Table 2).

\section{Molecular results}

A heterozygous TGIF1 c.82T>C;p.Ser28Pro variant was identified with targeted gene panel sequencing. This is classified as a variant of uncertain significance according to ACMG/AMP. The variant is absent in ExAC, GnomAD, and the Brazilian population databases (SELA and ABraOM) (Table 3). His unaffected mother and halfbrother also are heterozygous for this variant (Figure 4B). The serine at position 28 is well conserved among species (Figure 4D).

\section{Discussion}

We identified variants in three hypopituitarism genes in four Brazilian patients using next generation sequencing.

\section{GH1 gene}

GH1 was the first gene recognized as a monogenic cause of isolated growth hormone deficiency (IGHD) in $1981^{19}$. The gene encoding $\mathrm{GH} 1$ is located on the long arm of chromosome 17 (17q22-24) in a cluster of five related genes, including two chorionic somatotropin genes CHS1 and CHS2, the CSHP1 pseudogene and GH2, which is a variant of growth hormone expressed in the placenta. GH1 consists of five exons and four introns, and the primary protein product is $22 \mathrm{kDa}^{20}$. IGHD is classified in four subcategories: autosomal recessive (type IA and IB), autosomal dominant (type II) and X-linked (type III). Type IB is a rare form of IGHD (2\%), featuring short stature, low serum $\mathrm{GH}$ concentrations and good response to treatment with $\mathrm{rhGH}$, without 
formation of antibodies. It is more frequent in consanguineous families, and $\mathrm{GH} 1$ mutations can be frameshift, missense, homozygous nonsense, or splice site mutations in $\mathrm{GH}{ }^{21}$. This patient was classified as type IB due to his clinical characteristics, good response to treatment with recombinant human $\mathrm{GH}(\mathrm{rhGH})$, and the likelihood that the early frameshift creates a loss of function. Therefore, the allelic variant that we report GH1 c.171delT (p. Phe 57Leufs*43) is a new, pathogenic variant.

\section{SOX3 gene}

A variety of gain and loss of function mutations have been identified in SOX3, including gene duplication, deletion, alanine tract expansion, and missense variants. The patient phenotypes are variable, even within a family, and can include intellectual disability, midline and forebrain abnormalities, isolated growth hormone deficiency, or combined pituitary hormone deficiencies ${ }^{22}$.

Alatzoglou et al., described the association of SOX3 with topical neurohypophysis and the craniopharyngeal channel persists, which can be explained by the redundant function of the other SOX proteins that are necessary in the different stages of pituitary development ${ }^{23}$.

Two previously reported missense variants, p.Ser150Tyr ${ }^{24}$ and p.Pro142Thr 25, are located in the N-terminal tail of the HMG (High Mobility Group) domain of SOX3, and the patients presented with a complex phenotype of syndromic combined pituitary hormone deficiency. Cell culture studies demonstrated that the p.Pro142T variant increases SOX3-mediated transcriptional activation of HESX1 and diminishes repression of $\beta$-catenin-mediated transcription ${ }^{25}$. Although no functional studies are reported for the p.Ser150Tyr variant, the inheritance pattern is consistent with pathogenicity, as three affected brothers were hemizygous and multiple carrier females were unaffected. The lack of effect in females may be explained by preferential inactivation of the abnormal X chromosome ${ }^{26}$.

The SOX3 p.Met304lle we identified is located just outside the SOXp domain, which is a highly conserved domain ending in codon 302 . Variant segregation in the family conforms to expectations, as only the patient carried the variant in a hemizygous state. His mother and sister were unaffected carriers. Protein stability prediction tools are consistent with a destabilizing effect of this variant and two reported missense variants. According to ACMG, the p.Met304lle variant is classified as a VUS as there is insufficient evidence in favor of pathogenicity. The p.Met304lle is in a region that has low coverage in GnomAD, making it harder to accurately determine its frequency. It is reported in TOPMed (ss3623368805) but there is no genotype information, nor frequency. The family segregation and in silico studies favor classification of the variant as causative.

\section{TGIF1 gene}

We identified two TGIF1 variants that were absent in ExAC and gnomAD, as well as in the Brazilian population databases (SELA and ABraOM). TGIF1 (c.268C>T:p.Arg90Cys) was identified in the present study by whole exome sequencing in a patient with features of HPE and combined pituitary hormone deficiency. This variant was reported as a de novo mutation in a fetus with alobar HPE, hypotelorism, median cleft lip and premaxillary agenesis, without report of pituitary hormone status ${ }^{27}$. Later, functional studies confirmed that the p.Arg90Cys variant 
abolishes binding to the TGIF consensus site, reduces the TGIF1 repression mode of interaction through SMAD3 and $R X R^{28}$. Thus, this variant is pathogenic.

We identified a new TGIF1 variant (c.82T>C:p.Ser28Pro) in a patient evaluated by targeted gene panel. The patient had LH, GH and ACTH deficiencies, pituitary aplasia, interrupted pituitary stalk, and ectopic posterior lobe but no major cerebral malformations. This variant affects the same codon as a previously reported missense mutation (c.83C>T:pSer28Cys) found in a patient with midline defects ${ }^{29 ; 30}$. This TGIF region contains a conserved motif (PLDLS) with an important transcriptional repression activity. Previous functional studies demonstrated that $p$.Ser28Cys results in decreased RXR and TGF $\beta$ dependent transcriptional repression and loss of CtBP interaction ${ }^{28}$. Although this variant is classified as variant of uncertain significance (ACMG/AMP), it seems plausible that it is pathogenic.

Tatsi et al. reported a female patient with solitary central incisor, low $\mathrm{GH}, \mathrm{TSH}$ and gonadotropins, adenohypophysis hypoplasia, absence of the pituitary stalk and ectopic posterior pituitary lobe but no HPE brain defects. The patient and her asymptomatic father carried a heterozygous c.799C>T, p.Q267X TGIF1 variant, predicting truncation of TGIF1 and loss of the last 5 amino acids ${ }^{31}$.

To the best of our knowledge, the patient reported here is the first with CPHD and a TGIF1 variant without HPE or craniofacial midline defects.

\section{Conclusion}

In conclusion, we have found four allelic variants in 3 genes in hypopituitarism patients. We discuss these variants and associated patient phenotypes in relation to previously reported variants in these genes, expanding our knowledge of the phenotypic spectrum in patient populations. 
Table 1: Phenotype and Endocrine investigations of Patients

\begin{tabular}{|c|c|c|c|c|c|c|c|c|c|c|c|c|}
\hline Patient & $\begin{array}{l}\text { Age at } \\
\text { Testing } \\
\text { in years }\end{array}$ & $\begin{array}{l}\text { Initial } \\
\text { Height } \\
\text { SDS }\end{array}$ & $\begin{array}{l}\text { Puberty } \\
\mathrm{I} / \mathrm{S} \\
\text { (Years) }\end{array}$ & $\begin{array}{l}\text { Final } \\
\text { Height } \\
\text { SDS }\end{array}$ & $\begin{array}{l}\text { Target } \\
\text { Height } \\
\text { SDS }\end{array}$ & $\begin{array}{l}\text { GH } \\
\text { peak } \\
\mu \mathrm{g} / \mathrm{L}\end{array}$ & $\begin{array}{l}\text { Cortisol } \\
\text { peak } \\
\text { nmol/L } \\
(\mathrm{NR} \\
>550 \text { ) }\end{array}$ & $\begin{array}{l}\text { FT4 } \\
\text { pmol/L } \\
\text { (NR) }\end{array}$ & $\begin{array}{l}\text { TSH } \\
\mathrm{mU} / \mathrm{L} \\
(\mathrm{NR})\end{array}$ & $\begin{array}{l}\text { IGF1 } \\
\mathrm{ng} / \mathrm{ml} \\
\text { (NR) }\end{array}$ & $\begin{array}{l}\text { IGFBP } \\
3 \\
\mathrm{mg} / \mathrm{L} \\
(\mathrm{NR})\end{array}$ & $\begin{array}{l}\mathrm{PRL} \\
\mathrm{mU} / \mathrm{L} \\
(\mathrm{NR})\end{array}$ \\
\hline 1 & 9.5 & -7.65 & $S(14)$ & -0.63 & -0.63 & $\begin{array}{l}<0.2 \\
5\end{array}$ & NA & NA & $\begin{array}{l}6.0 \\
(0.5- \\
4.4)\end{array}$ & NA & NA & 54 \\
\hline 2 & 6 & $-4,67$ & $S(13)$ & -3.2 & $-0,7$ & 0.9 & 552 & $\begin{array}{l}0.97 \\
(0.7- \\
1.5)\end{array}$ & $\begin{array}{l}2.37 \\
(0.5- \\
4.4)\end{array}$ & $\begin{array}{l}200 \\
(227- \\
964)\end{array}$ & $\begin{array}{l}4,2 \\
(3,3- \\
5,7)\end{array}$ & $\begin{array}{l}340 \\
(<450)\end{array}$ \\
\hline 3 & 0.66 & -4.8 & - & $\begin{array}{l}\text { still } \\
\text { growin } \\
\text { g }\end{array}$ & +0.55 & $\begin{array}{l}0.15 \\
*\end{array}$ & 39 & $\star *$ & $\begin{array}{l}6.3 \\
(0-20)\end{array}$ & $\begin{array}{l}25 \\
(48- \\
313)\end{array}$ & NA & $\begin{array}{l}278 \\
(57- \\
717)\end{array}$ \\
\hline 4 & 4.9 & -4.55 & I (15) & -0.93 & 0.34 & 0.4 & NA & $* * *$ & $\begin{array}{l}3.11 \\
(0.5- \\
4.2)\end{array}$ & $\begin{array}{l}<18 \\
(25- \\
68)\end{array}$ & $\begin{array}{l}0.4 \\
(1,5- \\
3,4)\end{array}$ & $\begin{array}{l}42.5 \\
(42.5- \\
170)\end{array}$ \\
\hline
\end{tabular}

Induced- I, Spontaneous-S; SDS; standard deviation score, NR; normal range, NA; not available. *basal during hypoglycemia of $27 \mathrm{mg} / \mathrm{dL}$, ${ }^{* *}$ Total T4 - $6.68 \mathrm{RV} 4.5-22.2,{ }^{* * \star}$ Total T4 10.2 (7.7 - 49.8), GH cut off $>3.3$ mcg/L (IFMA)

Table 2: Molecular diagnosis and clinical and image patient's features

\begin{tabular}{|c|c|c|c|c|c|c|}
\hline Patient & $M / F$ & Gene & Allelic Variant & Inheritance & Hormone deficiencies & MRI \\
\hline 1 & $M$ & $\mathrm{GH} 1$ & p.Phe57Leufs*43 & AR & $\begin{array}{l}\text { IGHD } \\
\text { HyperHypogon }\end{array}$ & $\begin{array}{l}\text { TPP } \\
\text { Normal } \\
\text { AP }\end{array}$ \\
\hline 2 & $M$ & SOX3 & p.Met304lle & X-linked & IGHD & $\begin{array}{l}\text { EPP } \\
\text { AP } \\
\text { aplasia }\end{array}$ \\
\hline 3 & $\mathrm{~F}$ & TGIF1 & p.Arg90Cys & $A D-I C$ & $\begin{array}{l}\mathrm{GH}, \mathrm{TSH}, \mathrm{ACTH}, \mathrm{PRL} \\
\text { and ADH }\end{array}$ & HPE \\
\hline 4 & $M$ & TGIF1 & p.Ser28Pro & $A D-I C$ & $\begin{array}{l}\text { GH, TSH, ACTH, } \\
\text { LH/FSH, PRL }\end{array}$ & $\begin{array}{l}\text { EPP } \\
\text { AP } \\
\text { aplasia }\end{array}$ \\
\hline
\end{tabular}

$M / F$, male/female; $M R I$, magnetic resonance imaging; $A R$ autosomal recessive, $A D$ autosomal dominant, IC Incomplete penetrance, IGHD, Isolated growth hormone deficiency, HyperHypogon, hypergonadotropic hypogonadism; DI diabetes insipidus; AP, anterior 
pituitary; EPP, ectopic posterior pituitary; TPP, topic posterior pituitary; holoprosencephaly (HPE),

Table 3: Allelic variant classification according to ACMG

\begin{tabular}{|c|c|c|c|c|c|c|}
\hline Gene & Variant & OMIM / Genecards & gnomAD & ABraOM & $\begin{array}{l}\text { SELAd } \\
\text { b }\end{array}$ & ACMG \\
\hline GH1 & $\begin{array}{l}\text { c.171delT; } \\
\text { p.Phe57Leufs*43 } \\
\text { (17:61995706:A:) }\end{array}$ & $\begin{array}{l}\text { never related to } \\
\text { hypopituitarism }\end{array}$ & Absent & Absent & Absent & Patogenic \\
\hline SOX3 & $\begin{array}{l}\text { c.912G>A;p.Met30 } \\
\text { 4lle } \\
\text { (X:139586314:C:T } \\
\text { ) }\end{array}$ & $\begin{array}{l}\text { never related to } \\
\text { hypopituitarism }\end{array}$ & Absent & Absent & Absent & VUS \\
\hline TGIF1 & $\begin{array}{l}\text { c.268C>T: } \\
\text { p.Arg90Cys } \\
(18: 3457387: C: T)\end{array}$ & $\begin{array}{l}\text { never related to } \\
\text { hypopituitarism }\end{array}$ & Absent & Absent & Absent & $\begin{array}{l}\text { Likely } \\
\text { patogenic }\end{array}$ \\
\hline TGIF1 & $\begin{array}{l}\text { c.82T>C;p.Ser28P } \\
\text { ro } \\
(18: 3456417: T: C)\end{array}$ & $\begin{array}{l}\text { never related to } \\
\text { hypopituitarism }\end{array}$ & Absent & Absent & Absent & VUS \\
\hline
\end{tabular}

VUS variant of unknown significance

Figures

Figure 1- Characteristics of the pedigree with the GH1 c.171delT (p. Phe 57Leufs*43) allelic variant A. Pedigree of Patients 1 with segregation in recessive inheritance pattern $\mathbf{B}$. Photographs (obtained with permission) of the proband (II.3) and his sister (II.3) with features of growth hormone deficiency.

Figure 2 - (A) Family pedigree showing segregation of SOX3 p.Met304lle variant. Male patient was the only one affected (III.2). Letters below each family member represents the genotype, considering $G$ the wild type base and $A$ the variant.

(B) Protein diagram for SOX3. Only the missense variants mentioned in text are shown. Homeodomain and SOXp domains are highlighted, as well as portion of the protein containing amino acid repeats.

(C) Protein (left) and cDNA (right) conservation across species for SOX3. In bold, the codon and base mutated in p.Met304lle, showing that across multiple species, both are highly conserved.

Figure 3 - SOX3 mRNA structure change. While the p.Met304Val variant maintains the same structure as the wild type (WT) variant, the p.Met304lle, present in the patient, loses a hairpin formation in the mRNA.

Figure 4- Family pedigrees showing segregation of TGIF1 allelic variant (A) Missense human variants of TGIF1 with previous functional study demonstrating loss of protein function and gene domains and variants in bold from the present study 
(B) Family pedigree showing segregation of TGIF1 p.Ser28Pro variant. This variant was confirmed in his non-affected mother and half-brother.

(C) Family pedigree showing segregation of TGIF1 p.Arg90Cys variant. This variant was confirmed in her non-affected sister and father.

(D) Protein (left) and cDNA (right) conservation across species for TGIF1. In bold, the codon and base mutated in p.Ser28Pro, showing high conservation across multiple species.

(E) Protein (left) and cDNA (right) conservation across species for TGIF1. In bold, the codon and base mutated in p.Arg90Cys, showing highly conservation across multiple species.

References

1 CASTINETTI, F. et al. [Clinical and genetic aspects of combined pituitary hormone deficiencies]. Ann Endocrinol (Paris), v. 69, n. 1, p. 7-17, Feb 2008. ISSN 00034266. Disponível em: < https://www.ncbi.nlm.nih.gov/pubmed/18291347 >.

2 COHEN, L. E. Genetic disorders of the pituitary. Curr Opin Endocrinol Diabetes Obes, v. 19, n. 1, p. 33-9, Feb 2012. ISSN 1752-2978. Disponível em: < http://www.ncbi.nlm.nih.gov/pubmed/22157402 >.

3 FANG, Q. et al. Genetics of Combined Pituitary Hormone Deficiency: Roadmap into the Genome Era. Endocr Rev, v. 37, n. 6, p. 636-675, Dec 2016. ISSN 1945-7189. Disponível em: < https://www.ncbi.nlm.nih.gov/pubmed/27828722 >.

4 OTTO, A. P. et al. Frequent development of combined pituitary hormone deficiency in patients initially diagnosed as isolated growth hormone deficiency: a long term follow-up of patients from a single center. Pituitary, v. 18, n. 4, p. 561-7, Aug 2015. ISSN 1573-7403. Disponível em: < https://www.ncbi.nlm.nih.gov/pubmed/25315032 $>$.

5 BASHAMBOO, A. et al. A Nonsense Mutation in the Hedgehog Receptor CDON Associated With Pituitary Stalk Interruption Syndrome. J Clin Endocrinol Metab, v. 101, n. 1, p. 12-5, Jan 2016. ISSN 1945-7197. Disponível em: < https://www.ncbi.nlm.nih.gov/pubmed/26529631 >.

6 GIRI, D. et al. Novel FOXA2 mutation causes Hyperinsulinism, Hypopituitarism with Craniofacial and Endoderm-derived organ abnormalities. Hum Mol Genet, v. 26, n. 22, p. 4315-4326, 11 2017. ISSN 1460-2083. Disponível em: < https://www.ncbi.nlm.nih.gov/pubmed/28973288 >.

$7 \quad$ SIMM, F. et al. Identification of SLC20A1 and SLC15A4 among other genes as potential risk factors for combined pituitary hormone deficiency. Genet Med, v. 20, n. 7, p. 728-736, 07 2018. ISSN 1530-0366. Disponível em: < https://www.ncbi.nlm.nih.gov/pubmed/29261175 >.

8 SMITH, J. D. et al. Exome sequencing identifies a recurrent de novo ZSWIM6 mutation associated with acromelic frontonasal dysostosis. Am J Hum Genet, v. 95, n. 2, p. 235-40, Aug 2014. ISSN 1537-6605. Disponível em: < https://www.ncbi.nlm.nih.gov/pubmed/25105228 >. 
SYNOFZIK, M. et al. PNPLA6 mutations cause Boucher-Neuhauser and Gordon Holmes syndromes as part of a broad neurodegenerative spectrum. Brain, v. 137, n. Pt 1, p. 69-77, Jan 2014. ISSN 1460-2156. Disponível em: < https://www.ncbi.nlm.nih.gov/pubmed/24355708 >.

TAKAGI, M. et al. A novel KAL1 mutation is associated with combined pituitary hormone deficiency. Hum Genome Var, v. 1, p. 14011, 2014. ISSN 2054-345X. Disponível em: < https://www.ncbi.nlm.nih.gov/pubmed/27081504 >.

TATA, B. et al. Haploinsufficiency of Dmxl2, encoding a synaptic protein, causes infertility associated with a loss of GnRH neurons in mouse. PLoS Biol, v. 12, n. 9, p. e1001952, Sep 2014. ISSN 1545-7885. Disponível em: < https://www.ncbi.nlm.nih.gov/pubmed/25248098 >.

THAKUR, M.; TAHA, D.; MISRA, V. K. A Case of Congenital Hypopituitarism Associated With a 1p31 Microdeletion: A Possible Role for. J Endocr Soc, v. 1, n. 4, p. 278-282, Apr 2017. ISSN 2472-1972. Disponível em: < https://www.ncbi.nlm.nih.gov/pubmed/29264484 >.

TOMMISKA, J. et al. Two missense mutations in KCNQ1 cause pituitary hormone deficiency and maternally inherited gingival fibromatosis. Nat Commun, v. 8, n. 1, p. 1289, 11 2017. ISSN 2041-1723. Disponível em: < https://www.ncbi.nlm.nih.gov/pubmed/29097701 >.

WEBB, E. A. et al. ARNT2 mutation causes hypopituitarism, post-natal microcephaly, visual and renal anomalies. Brain, v. 136, n. Pt 10, p. 3096-105, Oct 2013. ISSN 1460-2156. Disponível em: < https://www.ncbi.nlm.nih.gov/pubmed/24022475 >.

MILLER, S. A.; DYKES, D. D.; POLESKY, H. F. A simple salting out procedure for extracting DNA from human nucleated cells. Nucleic Acids Res, v. 16, n. 3, p. 1215, Feb 1988. ISSN 0305-1048. Disponível em: < https://www.ncbi.nlm.nih.gov/pubmed/3344216 >.

NASLAVSKY, M. S. et al. Exomic variants of an elderly cohort of Brazilians in the ABraOM database. Hum Mutat, v. 38, n. 7, p. 751-763, 07 2017. ISSN 1098-1004. Disponível em: < https://www.ncbi.nlm.nih.gov/pubmed/28332257 >.

LERARIO, A. M. et al. SELAdb: A database of exonic variants in a Brazilian population referred to a quaternary medical center in São Paulo. Clinics (Sao Paulo), v. 75, p. e1913, 2020. ISSN 1980-5322. Disponível em: < https://www.ncbi.nlm.nih.gov/pubmed/32785571 >.

TAKEICHI, M. Functional correlation between cell adhesive properties and some cell surface proteins. J Cell Biol, v. 75, n. 2 Pt 1, p. 464-74, Nov 1977. ISSN 0021-9525. Disponível em: < https://www.ncbi.nlm.nih.gov/pubmed/264120 >.

PHILLIPS, J. A. et al. Molecular basis for familial isolated growth hormone deficiency. Proc Natl Acad Sci U S A, v. 78, n. 10, p. 6372-5, Oct 1981. ISSN 00278424. Disponível em: < https://www.ncbi.nlm.nih.gov/pubmed/6273867 >.

GIORDANO, M. Genetic causes of isolated and combined pituitary hormone deficiency. Best Pract Res Clin Endocrinol Metab, v. 30, n. 6, p. 679-691, Dec 2016. ISSN 1878-1594. Disponível em: < https://www.ncbi.nlm.nih.gov/pubmed/27974184 >. 

North Am, v. 36, n. 1, p. 17-36, Mar 2007. ISSN 0889-8529. Disponível em: < https://www.ncbi.nlm.nih.gov/pubmed/17336732 >.

ALATZOGLOU, K. S.; DATTANI, M. T. Genetic forms of hypopituitarism and their manifestation in the neonatal period. Early Hum Dev, v. 85, n. 11, p. 705-12, Nov 2009. ISSN 1872-6232. Disponível em: < https://www.ncbi.nlm.nih.gov/pubmed/19762173 >.

ALATZOGLOU, K. S. et al. SOX3 deletion in mouse and human is associated with persistence of the craniopharyngeal canal. J Clin Endocrinol Metab, v. 99, n. 12, p. E2702-8, Dec 2014. ISSN 1945-7197. Disponível em: < https://www.ncbi.nlm.nih.gov/pubmed/25140394 >.

JELSIG, A. M. et al. A complex phenotype in a family with a pathogenic SOX3 missense variant. Eur J Med Genet, v. 61, n. 3, p. 168-172, Mar 2018. ISSN 18780849. Disponível em: < https://www.ncbi.nlm.nih.gov/pubmed/29175558 >.

$\mathrm{YU}, \mathrm{T}$. et al. Increased transactivation and impaired repression of $\beta$-cateninmediated transcription associated with a novel SOX3 missense mutation in an Xlinked hypopituitarism pedigree with modest growth failure. Mol Cell Endocrinol, v. 478, p. 133-140, 12 2018. ISSN 1872-8057. Disponível em: < https://www.ncbi.nlm.nih.gov/pubmed/30125608 >.

ALATZOGLOU, K. S. et al. Increased transactivation associated with SOX3 polyalanine tract deletion in a patient with hypopituitarism. J Clin Endocrinol Metab, v. 96, n. 4, p. E685-90, Apr 2011. ISSN 0021-972x.

CHEN, C. P. et al. Molecular diagnosis of a novel heterozygous 268C-->T (R90C) mutation in TGIF gene in a fetus with holoprosencephaly and premaxillary agenesis. Prenat Diagn, v. 22, n. 1, p. 5-7, Jan 2002. ISSN 0197-3851. Disponível em: < https://www.ncbi.nlm.nih.gov/pubmed/11810641 >.

EL-JAICK, K. B. et al. Functional analysis of mutations in TGIF associated with holoprosencephaly. Mol Genet Metab, v. 90, n. 1, p. 97-111, Jan 2007. ISSN 10967192. Disponível em: < https://www.ncbi.nlm.nih.gov/pubmed/16962354 >.

GRIPP, K. W. et al. Mutations in TGIF cause holoprosencephaly and link NODAL signalling to human neural axis determination. Nat Genet, v. 25, n. 2, p. 205-8, Jun 2000. ISSN 1061-4036. Disponível em: < https://www.ncbi.nlm.nih.gov/pubmed/10835638 >.

MELHUISH, T. A.; WOTTON, D. The interaction of the carboxyl terminus-binding protein with the Smad corepressor TGIF is disrupted by a holoprosencephaly mutation in TGIF. J Biol Chem, v. 275, n. 50, p. 39762-6, Dec 2000. ISSN $0021-$ 9258. Disponível em: < https://www.ncbi.nlm.nih.gov/pubmed/10995736 >.

TATSI, C. et al. Pituitary stalk interruption syndrome and isolated pituitary hypoplasia may be caused by mutations in holoprosencephaly-related genes. J Clin Endocrinol Metab, v. 98, n. 4, p. E779-84, Apr 2013. ISSN 1945-7197. Disponível em: < https://www.ncbi.nlm.nih.gov/pubmed/23476075 >. 